\title{
Ethnographic Inquiry at the Library: Analyzing Relations to Understand the Barriers to Public Reading
}

\author{
Mariangela Roselli \\ Department of Sociology, University of Toulouse 2-Jean Jaurès, Toulouse, France
}

Email address:

roselli@univ-tlse2.fr

\section{To cite this article:}

Mariangela Roselli. Ethnographic Inquiry at the Library: Analyzing Relations to Understand the Barriers to Public Reading. American Journal of Information Science and Technology. Vol. 5, No. 1, 2021, pp. 1-11. doi: 10.11648/j.ajist.20210501.11

Received: November 16, 2020; Accepted: December 1, 2020; Published: January 25, 2021

\begin{abstract}
A number of sociological inquiries over the last twenty years have demonstrated the pertinence and usefulness of an ethnographic approach to studying the relationship between library users and professionals, between the users and the "objects" on offer at the library, and between people and the spaces created for them. the interactions observed in libraries show the social ties of class and gender which, reinforced by the effects of age and generational differences, drive social segmentation from within the library. despite the sequence of reforms that have changed the mission of french libraries since the $1980 \mathrm{~s}$, there remains a vast section of the french population that never steps foot in a library, even if one is located close to home or where they work or study. since physical inaccessibility is not the problem, what is? During a round table at the conference of the Association of French Librarians (ABF) in June 2017, the issue of the social inequalities that are created and amplified by the relationship between library staff and publics and between books and publics was identified as one of libraries' greatest challenges. librarians now admit that the "library apparatus" produces inequalities. it is an "apparatus" in the foucauldian sense, simultaneously a discourse, site and tool of power that aims to define, discipline and order knowledge; its structural characteristics themselves can deter the entrance of people unaccustomed to places of culture and thus favor their self-exclusion: imposing architecture, austere layout, minimalist decoration, coded displays and signs, majority female staff, and professional jargon are so many dimensions of a space that remains autoreferential and closed off. akin to schools in their link to written texts and established knowledge, libraries are socially-marked sites, expressions of separate territoriality within a neighborhood, city, or even a university campus. by proclaiming in every way and direction the absolute dominion of the written word, the library erects a silent but powerful boundary between those who master this realm of the word - absorbed as an aesthetic education more than it is learnt at school - and use it in their work, their free time, their culture, curiosity and emancipation, and those who dwell outside of the lettered, de facto socially-dominated world.
\end{abstract}

Keywords: Libraries, Class and Gender Inequalities, Literacy and Symbolic Barriers

\section{Why and How to Study Relations in the Library}

Officials in the service of the State, librarians embody this literary logic, champions of the written word and of the ideal of emancipation that reading provides, transmitters of culture in the dual sense of the term, legitimate culture and cultural democracy. Of the principal missions with which librarians are entrusted, one to which they are particularly committed is the task of welcoming, assisting and orienting the publics in their choice of reading and cultural consumption, to promote the assimilation of resources by individuals and social groups of the territory in which the library is rooted. In its attempt to reflect on professional practices in the library, the ABF conference examined this daily activity by asking questions of internalized routine and patterns, of the social prejudices and tendencies of the professionals as potential drivers in the production of inequalities [17] inside the library - all types of public reading establishments, including media libraries, libraries-on-wheels and university libraries [42].

\subsection{What the Sociological Perspective Sees in the Library}

In the 1980s and '90s, a number of sociologists demonstrated that French libraries contributed to keeping the working-class public at a distance by their method of 
selecting and displaying books. [38, 39] The observation of a powerful cultural complicity between professionals of the book and cultivated readers functions as a powerful mechanism for deterring working-class publics from public institutions of culture [31].

Over the last thirty years, libraries in France have multiplied, diversified and modernized, becoming multimedia libraries that are often welcoming and comfortable and developing a range of services and a rich selection of reading material (early childhood, students, newspapers, internet users, citizens in need of computer equipment); library workers were obliged to reflect on the crucial importance of welcoming visitors and interactions with their publics, pluralized to underline both their diversity and the disparity in their cultural tastes and practices. According to studies regularly conducted by the French Ministry of Culture and Communication, libraries are becoming progressively more democratic [26]: more than two-thirds of those surveyed in 2015 had visited a library at least once in their life, and $65 \%$ knew of a library close to their residence. Youth and high level of study are the two most common factors among library users. Yet there are at least two other driving forces at work in the division between users and non-users of libraries: the female dimension that the image of the library takes on and the generational preferences for "real" readers (of books).

The French library reinforces these differences, rather than reducing or inverting them. Librarians forget that without daily attention to the mechanisms of social differentiation, the social domination of individuals and social groups is visibly and directly translated into exclusion. While it is true that individuals' cultural capital and the class culture of social groups already contain the social and economic dimension of social ties, it is also true that there are places - schools, libraries, museums, theaters or music halls - that crystallize the consequences of social, economic, professional, and even territorial inequalities, and intensify their effects. These institutional sites amplify the positions of groups in social contacts by adding to them an aesthetic and symbolic dimension that eludes the acquisition of knowledge in school and resists any and all processes of interiorization, even later in life. What Pierre Bourdieu called "cultural capital" [6] is not only defined by the number and quality of one's titles and diplomas, but also by the precocious absorption of skills, abilities, sensibilities and virtues that eventually become second nature in what Edmond Goblot called the "bourgeois education" [16].

If survey-based statistical data has long shown the constant and durable segmentation of library publics, with the constant absence of the same social groups (farmers, artisans, storekeepers, company managers) and the weak presence of certain others (laborers and low-level employees, namely, i.e. the working class), it also underlines the permanence of this phenomenon despite the concrete scholastic and cultural democratization efforts in France over the last half-century. Research in the Sociology of Culture [22], the Sociology of Cultural Practices [7], and the Sociology of Reading [3, 19] highlight the dual influence of a school entirely won over to classic literature and legitimate culture, prerogative and distinction of the privileged classes. These studies show how the school systems showcases eclecticism in reading as a gift, rather than developing it as a skill to be constructed.

This characteristic of the products of the French school system is found in the functionaries of certain cultural establishments, libraries included, and it carries on working at full capacity if it is not identified, questioned, debated and reworked by library personnel. Throughout the inquiries conducted in libraries, the central question is to see how the interactions between people and things reflect the mechanisms of inclusion/exclusion that lie at the foundation of the closed, silent place that the library continues to be despite the changes in mission, audience, and service offering that have been implemented in France for over thirty years. The common thread emerging from the various studies - in local libraries as in big-city multimedia libraries, and even in university libraries - is that of a boundary, quite visible and nearly insurmountable, between the group that maintains the categorized, ordered world behind the text as its mission and ideal, and, on the other side, the daily, real agitation that is life - with its contradictions, its multiple truths, its insoluble disorder. Upholding this boundary reassures those within and discourages those without, an outside where residents, passersby, and even certain students continue to feel that it isn't a place for them.

\subsection{The "Territory of the Library" as Border: The Complementary Contribution of Ethnographic Inquiry}

The ethnographic approach first established itself in the library as a tool for analyzing professional practices. At the request of the management of several large institutions, such as the Centre Pompidou's Public Library of Information, the National Library, even the General Management of Libraries in the Ministry of Culture, ethnologists, sociologists, political scientists and ergonomists have been called to study the daily practices of librarians and the behavior of the publics (social groups such as the homeless or the poor, youths and adolescents, students, internet users, visitors, retirees, etc.) to help library professionals acquire greater reflexivity through an external perspective $[34,32,47]$. This is first and foremost a tool for raising awareness, through the scrupulous, detailed, and in-depth description of the situations that occur daily in a library and that often go unobserved by the staff, either because they find them unimportant or because they are busy with other interactions. In fact, the ethnographic approach as theorized and applied by American urban anthropologists of the 1950's and 1960's such as James Spradley [54] reveals what normally remains unseen, highlighting the interpersonal contacts present in a given situation and the effects of a "cultural framework" [24] on people's behaviors, choices and decisions.

All of these ethnographic studies, in fact, show that actors involved on a daily basis in a closed frame of action regulated by its own interior code end up losing sight of what is actually happening and how common practices gradually 
shape not only their point of view, but even their body language and gestures. Ethnographic inquiry puts actors' behaviors and routines in the spotlight, accepting the fact that all actors, even the most "transparent," are guided by logics and forms of rationality that end up structuring the relations between the various actors, on the one hand, and between the actors and space on the other. Watching actors do and do to one another reciprocally is the objective of the ethnographic method, with a particular focus on interactions as social situations that produce social frameworks with their own norms, codes and references.

The heuristic hypothesis consists in arguing that a library does not have its own morphology and "nature," but that it is composed and recomposed based on what the actors do, in both the front and back office. By "actors," we mean the library staff present in the institution's public areas as well as those who create the library, organizing it according to their point of view, with their expectations and representations of its aims and its recipients. The "readers" - imagined, idealized, sought after and (more or less) encouraged by the translation of these intentions into the layout of the library's spaces and shelves, are also actors that the ethnographic inquiry identifies, follows and observes in their behaviors, habits and preferences, including the repeated use of a place, object or media format.

Thanks to the numerous ethnographic studies since 2003, it is possible to describe the nature of the obstacles to library access, bringing to light the mechanisms that operate behind individual behaviors, detecting their logic and contributing to the comprehension of the inequalities libraries produce. It can be shown how certain libraries allow symbolic barriers between social classes to slip inside their doors, rendering their bookshelves "inaccessible" to readers of working-class origins who are quickly disoriented in the complexities of classification systems; how some libraries cultivate an atmosphere of order, constraint, restraint and authority [23] that attracts the well-read, the erudite, and medical students and drives away magazine readers, groups of teenagers [18, 55], and humanities students; how certain others design their spaces so as to encourage a public of women and children. It's no coincidence, for that matter, if libraries' privileged public remains females and mothers [25, 26], mirroring librarians' representation of the library and reading.

The profession and world of the library were built on the female presuppositions of openness toward others and maternity: in 2003, testimony collected throughout the world between 1993 and 2002 by the Women's Issues Commission of the International Federation of Librarians Associations (IFLA) almost universally associates the librarian's work with maternal functions. For French library professionals, humanity and social sensibility characterize the experience and perception of their job [1, 14]. The weight of these values was and remains staunchly supported by the staff's largely female make-up ${ }^{1}$ that influences not only the

1 Women represent $86 \%$ of the actors in group A (curators, head of shared documentation services) and $84 \%$ of actors of group B (librarians, archivists). [27] selection of available materials and the design of spaces, but even shapes a certain vision of reading. And while the profession is renewed in age and generational terms, the sexual division of tasks and specializations remains unchanged, with women tendentially dedicated to children and men to the services of the music library, video library, and even the libraries-on-wheels, which are driven and managed by male librarians. Likewise, though library teams in sensitive urban zones (ZUS, i.e., underserved and reputedly "difficult" neighborhoods) display a greater openness to social and ethnic mixing, professional statistics indicate that the "new recruits" nearly always occupy the roles of "mediator" and "instructor" and are always contract workers in precarious employment situations.

In various ways, engraved as much in interactions, spatial movements and prohibitions as in relationships to body, gesture, and suggested position, the library continues, unconsciously, to produce difference. As an institution, it crystallizes differentiations by categorizing individuals and groups according to behaviors, characteristics, and ways of doing, and by placing them in a hierarchy from the standpoint of what is normally allowed, expected and desired in a library, what is merely tolerated, and what is immediately or indirectly reprimanded, excluded, or penalized. It is thus not merely a question of names, for example, The difference between a "Children's" service and a "Youth" card is not merely a question of names, indeed, because they do not refer to the same category: a "Children's" service is intended and designed for children (in the 4-9 age bracket), while the "Youth" card refers to another, older youth - preteens, teenagers, and post-teens between 11 and 20 - who push the limits of prohibitions and rules and bend the library's spaces to original, even unexpected uses. What is happening here is a classifying of these two categories of young people, one of which is heartily and maternally welcomed, the other barely tolerated. Social stratification not only persists in the job and career hierarchy, but also reflects the growing employment insecurity for young working-class people, especially those with immigrant parents. The social morphology of library teams is, by itself, the expression visible to all - of the basic postulate of this institution which, while proclaiming its commitment to individual emancipation through culture, nonetheless conserves a hierarchy of place as a function of origin. The external observer sees these dissonances and disparities; the act of writing them down, mapping them out (as a geographer does for a territory), and presenting them with the cooling mechanism of scientific precaution ${ }^{2}$, enables us to use this material as a rich collection of significant situations that condense many of the types of interactions that occur in and around the library "apparatus."

\footnotetext{
2 Field logs, observation grids, all-out then targeted observations, verification methods of cross-referenced materials: all these precautions are explained and analyzed in our contribution to the methodology of inquiries in libraries [44].
} 


\subsection{Relations: The Origin and Engine of Social Ties}

In this framework, relations take center stage. We start from the hypothesis of librarians' specific and differentiated relationships with different social groups present in the various publics, according to their degree of familiarity with the apparatus staged by the library. These specific relations rely on the reciprocal representations and expectations of the library workers and users, such that the framework of interaction can be encouraging or, the contrary, obstructive. The groups' logics of action, on the same site, can be convergent and constructive, or create frameworks of tension, often stemming from confusion or misunderstandings on both sides. To grasp the centrality of professional/user relationship in the library, we have chosen to use the results of ethnographic inquiries to create user portraits [42] and delineate ethnographic "scenes" [54, 44]. Thanks to these detailed descriptions, drawn from studies conducted in local libraries, downtown multimedia libraries, intercommunity multimedia libraries in suburban areas, and, finally, university libraries, we propose to show that library professionals have 1) demands, 2) modes of communication, and 3) forms of mediation that adjust to the various publics they deal with, thus producing injunctions more or less likely to encouraging library use. Now, when the desire for culture and reading, particularly in the case of teenagers and young adults, goes through a female pedagogical figure [11], this attempt takes on the guise of an injunction to do and to do in a certain way. These injunctions can have a discouraging, deterring effect, particularly on teenage boys and especially those from the working classes, who mark their entrance to puberty by becoming part of a group of friends, listening to music, and rejecting books [29].

The relationship between library professionals and the public is a decisive factor in the segmentation of the publics of readers and users. In this reflection we reveal the pernicious mechanisms of this segmentation, often linked to a negative prejudice concerning individuals and social groups not easily regulated by the norms in force in libraries: being silent, sitting down, being alone. Three characteristics that are highly valued, even demanded by librarians. For example, the observation of an almost metonymic relationship between the object and the person who handles it (the book and the librarian) has been the subject of several North American studies that highlight the embodiment of the book in a highly-literate, pedagogical female figure, more supervisory than benevolent. Her attitude is felt to be hypercritical toward young people in general, and can create anxiety particularly in boys $[20,52]$. While these interactions are not conscious or deliberate, they nevertheless play a central role in discouraging and driving away individuals and groups poorer in cultural capital and less docile with the respect to the norms that govern the library apparatus [5], sheltering it from more restless groups. What's interesting about studying relations is grasping the messages of power and domination of one group over another that they implicitly contain.

\section{Public Segmentation Mechanisms}

To shed light on the process of differentiation of the public, we recall two case studies that help clarify the functioning of the mechanisms inscribed in the organization of libraries and in professional practices. The first is a mechanism of social domination that is a part of the morphology and design of the library itself and leads to the absence, via the self-exclusion, of working-class readers. The second is a mechanism of sexual preference for the female gender by female librarians, who craft a local library in the image of an elite high school documentation center. The scenes we describe come from observations in different types of libraries ${ }^{3}$ : local and intercommunity libraries situated in suburban areas, big-city neighborhood libraries, and a downtown media library. Their publics, of course, are more or less captive (university library [43]), more or less homogeneous (intercommunity library), diversified (downtown media library), and socially or geographically distinct (neighborhood library); the selection of reading material and services is not the same, and the resources allocated and available space simply aren't comparable. Yet they are all libraries, facilities for public reading and services, with the goal of providing access to resources for the population of a territory (or a campus, in the case of universities). Most of all, whatever the differences between the various types of libraries, there are certain recurring characteristics: firstly, the great homogeneity of the staff (female, white, middle-class), then the standardization of their offering (layout, presentation, organization, hierarchization of media, centrality of the book and lack of importance given to users and work tables), and, finally, a vigorous regulation through silence and the respect for the reader (to the detriment of less conforming groups and users). ${ }^{4}$ We will conclude this second part of the work by showing how the large multimedia libraries are sought out by the least conventional users (groups of young people, groups of students, groups of people exploring, non-reader users, solitary boy readers) due to the possibilities of acting in the margins of these spaces and being less visible (and less subject to the monitoring gaze of the staff).

\subsection{Solitary, Silent Reading: An Unattractive Model for Lower-Class Readers}

The working class's absence in the library forces us to patrol the terrain of observation inside as well as outside the library, in order to understand the effects of territory and context. We did this in several inquiries in "annex libraries," a term used in France to indicate their location in more or less well-to-do suburbs, or disadvantaged neighborhoods [48]. The regularity and permanence of the inequalities connected

3 Two techniques were used: clandestine observation and user tracking. Clandestine observation is made easier in public facilities where one can take the place of an ordinary user, letting interactions unfold without disturbance: this is the method of "sweeping the library". [15] The second technique is user tracking, which consists in following individuals' paths in a space. [42]

4 This observation is shared by all studies conducted abroad, and is only now beginning to gain ground as an issue in France and Europe more generally. [33] 
with public reading cannot be understood without exploring the blind spot of working-class lifestyles and the book's exotic place in working-class cultural practices [53, 51]. This is especially true since, at least for the moment, schools work against the idea of reading for pleasure, silently but ceaselessly sapping those poor in cultural capital because of their inability to decrypt the aesthetic and stylistic codes of classic literature [3].

Libraries of working-class neighborhoods are not deserted, though, because local schools, associations, and families from better-off neighborhoods occupy the spaces the neighborhood's residents leave free. Workshops of children's storytelling and reading aloud, music appreciation workshops, and presentations by comic book authors are events that citycenter dwellers don't miss, while locals find them of little or no interest. These occasions are ignored by the working class (laborers, low-level employees, housewives and their children), who do not perceive them as an offer intended for them, or services placed at their disposal. Yet in other countries, some poorer, some simply more sensitive to promoting working-class access to culture, information and documentary resources, the forms of the cultural offering have progressively adapted to customs and tastes of the lessacculturated social groups and their urban trajectories.

Even when teams of specialized library workers are trained for "difficult" publics, they don't attract young people from disadvantaged (economic, scholastic, social) situations; indeed the latter exclude themselves, not considering this place as a resource likely to be offered or proposed to them. Young people in working-class neighborhoods don't feel drawn to what the library represents, or what they imagine the library to be. The majority of them have never stepped foot in one, or only as elementary school students. In their minds the library is associated with books, school and homework, even with the female librarians who appear particularly hostile toward working-class youths.

Even after a first incursion/exploration in the library, in fact, many young and not-so-young people never go back: youths looking for employment; pre-teens searching for a hangout not too reminiscent of school; groups of teenagers who want to talk, thus making noise and disturbing the "real readers" who make up the only true public in the eyes of certain library professionals; migrants looking for a connection to speak with their family or immigrant residents in France, discouraged by the complex systems for searching for information or finding books.

For them the library remains hermetically sealed because the literate order that lies at its foundation is not a part of the working-class world, unlike in other countries where it is exported beyond those walls. It is a question of place: the books are inside walls, on shelves, buried in unintelligible classification systems, when the lower classes don't have the luxury of spending their free time in a closed, silent place where solitude and concentration are the accepted rules of the game. Going to the library is inconceivable as a pleasure if it doesn't fulfil some desire: to want to enter a library, the latter must be neither school (prescribed, difficult reading), nor after-school (homework), nor, much less, a sort of imprisonment in a constrained posture (still, silent, solitary). People won't accept to be constrained by one of these conditions unless the other two are removed. For example, in the annex library of a working-class, strongly-immigrant neighborhood in Toulouse in 2012 [46], a 12-year-old boy explains how the solitude that reading books requires isolates him from his male friends and, at the same time, guarantees him a privileged connection with a group of girls he really likes. If he's able to play at both tables, he specifies, it's only because he's just arrived in France (from Spain, with a Moroccan mother) and still isn't completely integrated in his group of friends (from his school and neighborhood) since his French isn't great. This clarification on the part of a young immigrant boy accurately sums up the divided situation he is experiencing: either he goes to the library to find books and improve his French, as he is doing when we meet him, or he gives in to the pressure of the group of other boys who call him to spend time outside, far from anything reminiscent of the scholastic order (books, homework, silence, immobility, concentration, injunctions transmitted by women). Pierre is aware that this period of the library will end when the excuse of improving his French is no longer sufficient to justify his being away from the group [50].

Reading at the library presumes being silent, concentrated, and still, and above all, choosing to be alone. Well, the working class doesn't generally find pleasure in solitary, silent leisure activities. They have no particular affinity for places where you shut yourself off to listen to music, much less appreciate a piece of literature. Adolescents from working-class families, and especially those of immigrant parents, are today the most likely group to define their emblematic way of being young by the fact that they don't read. The rare male junior high school students I have met at the library in working-class neighborhoods are either in noisy groups, and thus hassled by the librarians and security guards or mediators, or solitary boys who for one reason or another are unable to be part of a group. To attract them inside its walls, a library must take interest in the inhabitants of working-class neighborhoods, their lifestyles, their needs, expectations and customs, their day-to-day concerns. If it doesn't, it will remain an alien universe, too distant from real-life worries and, undoubtedly, too abstract and refined. Put another way, a cathedral in the desert.

\subsection{The Sexual Construction of Places, Media and Objects}

The specificity of social relations of gender can be grasped in the unique perspective that women librarians have on youth. This view is fueled partly by a sense of discordance between the silent and immobile world of the book to which the librarians are bound (culturally and emotionally) and the noisy, agitated world of youth; this gap between expectations and real-life habits is translated into a negative and hypercritical attitude toward young people, especially toward the boys with whom interactions in the library are tense, even conflictual. Given that hyperactivity and noise are characteristic of boys' exaggerated behavior, particularly 
when they are in situations of constraint, concentrated effort or surveillance, their relationship with the library and reading is not facilitated by female mediation. On the other hand, girls' ability to control themselves and be autonomous in study situations, as well as their body and gestural affinity to women librarians, constitute material elements that facilitate their proximity and mutual preference. Girls' abilities allow them to be immediately associated with "good readers," while boys, so to speak, start from a disadvantaged position. Ruses, tricks, and diversions are thus necessary to thwart the heavier surveillance to which they are subjected.

A scene observed in a local library in Toulouse in 2001 [40] confirms the evasive tactics boys adopt vis-à-vis this context: relations of familiarity between the library personnel and the neighborhood's young inhabitants are experienced as an identifying mark that, in a place of close supervision, at times becomes intolerable for the boys. Consequently they prefer to settle in just outside, beside the library. A boundary is created that the library contributes to institutionalizing, between the interior, realm of the girls, and the outside, world of the boys. The boundary, which takes material form in the library's great glass windows, stages the separation between inside and outside and what it symbolizes: the distancing by the boys, as a group, of the world of both girls and books, simultaneously.

The choice of the library's immediate surroundings questions the boys' logic but says a lot about the value of this place. What is played out around the library is contemporaneously the search for sociability, and the separation between a world of girls where school, the written word, homework and culture are generally positive, attractive values, and the world of boys where, to the contrary, such values function as deterrents. Original source of an individual's social marking and engine for the reproduction of roles, the rift between two different relationships with culture and, particularly, with reading (through the body posture bent over the page with pen in hand, embodied by girls) and school (through written homework, accepted by the girls and ostensibly refused by boys) offers the opportunity to update roles distributed by biological sex and zealously embodied by the gender that differentiates the two groups. Boy-girl differentiation emerges reinforced thanks to the social production of the female reader, which is also that of the non-male reader [21]. The wait outside the library takes on a particular meaning because it is woven into a time shared between boys and girls, between outside and inside, as though the two sides held each other together in a dialectic of social roles that, through the library, are institutionalized and staged. The two groups, one female, the other male, embody the cleavage to which the relationship with reading and institutional culture gives rise [10] from the moment that, during the construction of their personalities, girls and boys recognize themselves in a specific gender group. ${ }^{5}$ Here it is

\footnotetext{
5 We saw how in a downtown multimedia library, where social ties crystallize less around sex-based roles and more around the effects of age and generation, the display of virility as an essential attribute of the male group can be avoided: the concern downtown is to appear as part of the group encompassing high school
}

necessary to underline the cleavage between these two types of culture, and the social use to which it lends itself as a logical shortcut based on the difference between the biological sexes: this cleavage between institutional culture and entertainment culture becomes the receptacle of sexual identification, and, in turn, the engine of differentiated practices.

What boys reject in the library is firstly the solitude and the silence and the impossibility of discussing, debating, exchanging, speaking to one another, whispering, flirting, in short, behaving and displaying themselves in a visible space according to all of a boy's social characteristics. When you observe and take stock of what teenagers do in a multimedia library, you realize that they (both boys and girls) spend most of their time moving around, looking for one another and, once they find each other, spending time together [46].

The value of the group, of being together, suffers on this occasion due to the splitting into two groups, of girls and boys, an adaptation traversed by the social relations of age and sex [30]: the female group is sought after, approached and coveted not only for seduction but also because it is conserved and withdrawn in a place valued by society. Everything unfolds as though the game of seduction gained in importance from taking place according to an institutional codification and in the realm of the prohibited: here, the gaze of the adult - which is also a woman and a librarian - ideally fulfils the conditions of institutional recognition and boundary between the accepted and the unaccepted. But such a game only makes sense if it is broadcast by the group beyond the window pane, on the boundary line, between the inside - protected by the silence of abstraction - and the outside, synonym of real life, of concrete reality. The mechanism of differentiation thus takes material form through the barrier dividing the protected space from the space open to the public. This spatial frontier is symbolically located in the characteristics of the figure of the female reader and her male counter-figure [49].

The interior is represented by the closed space of the library, controlled and withdrawn from excessively noisy interactions. The library represents a protected, semi-public space where you cannot do whatever you want, and you can only get what you want by submitting to certain conditions and rules [36]. The exterior, on the other hand, is the truly open, public space, where young people feel they can claim the right to do things that have meaning for them, things that count. It is not libraries that embody public space, despite what the canonical definition of these institutions claim, but rather what lies outside them, as though the fact of being just beyond their walls but adjacent to them attributed, simultaneously, greater flexibility and a tolerable demand of conduct against excessive leniency. The boy desire to be between these two poles, neither too close to this world out of time, nor too far away. Three territories are thus identified and engaged, one associated with abstraction and effort, subjected to overly constraining regulation, the other full of

students, rather than as part of a separate group. [41, 51] 
potential and personal involvement. The third, quite tangible, charged with friction, smacking of boundary, is a symbolic territory where we measure the weight of representations on social relations of gender. In the end, it is a non-public space that is completely subjected to norms that are very difficult to evade; or that only readers who are firmly integrated into the institution, to the point of being able to attempt to bypass the prohibitions, can get around.

The division between interior and exterior clearly indicates what the interior is lacking, namely a certain freedom of movement, a certain leeway for undertaking interesting initiatives, a right to engage in activities that are not exactly in line with the staff's expectations. In the case of a local library, the public space par excellence with its mission of facilitating public access to culture, services and resources [4], this place is paradoxically situated at the opposite extreme from what young people desire in a public space. One wonders, indeed, if the social activities they want to share with their friends might not find a legitimate place in a part of the library dedicated to exchange, conversation and noise as a form of social activity in its own right, while recognizing that the same library could preserve certain zones regulated by silence. This cohabitation of place would reflect the hybridization of tastes in culture and entertainment while opening up the institutional space to social practices (meetings, chats, combined study-socializing interactions, flirting, relational and physical contact) that would find a form of expression by means of recognized and shared cultural media. In short, rather than encouraging the separation of study time and leisure time by maintaining a strict obligation to respect the rules and conditions of use, the local library, given its greater proximity to the neighborhood's residents, could stage a more elastic configuration of cohabitation between noise and silence (such as the Plexiglas dividers used in the library facilities of certain Berlin neighborhoods), young people and adults (spatialization of territories by different colors and media, but common areas around a coffee machine, as is the case for municipal libraries in England), and boys and girls (study tables in rooms separated by non-transparent walls adolescents are particularly sensitive to constant surveillance). [36]

\subsection{Attempts to Neutralize Differences in the Large Spaces of Multimedia Libraries}

At the opening of a large downtown Toulouse multimedia library with extended hours (including Sunday afternoons), a crowd of local citizens flooded in to explore the various areas and stroll freely through the vast spaces on four floors. They included a large number of young people from outlying neighborhoods, whole families, and people who typically show little interest in this type of institution. [41] The direct effect of the library's opening was to produce a new type of user: mobile and boisterous. There were adolescents (both younger and older), more boys than girls, who arrived as groups and remained in them. Groups are often structured around girls, a point of attraction and a safe-conduct for boys, who can thus remain in the library while gradually testing out its accepted limits. Indeed, the security guards called several months later to patrol the site intervene most often with groups of all boys, and more rarely with mixed groups in which girls function as a sort of passport permitting entrance. The girls neutralize, so to speak, the threat to the established order that the all-male group represents. ${ }^{6}$ These young, noisy users are those who most often develop strategies for circumventing and readapting resources and tools, for avoiding staff or cheating the rules. They are generally not well-liked by librarians, and their rare requests for assistance tend to be directed toward male colleagues, better with computers $^{7}$ but also more flexible concerning the rules. The bustle and noise created by young people walking around and exploring make them personae non gratae. And the female librarians who serve the public on Saturdays and on Sunday afternoons in this multimedia library display an allergy, even a sense of panic, brought on by the nonchalance of these youths and their ability to dodge the need for the written word by using equipment associated more with entertainment $[28,46]$ than knowledge. Reading, like watching a screen or listening to something, is for these young users a tool, a pretext, not an end in and of itself. Their situation is one of cultural entertainment, not the search for knowledge, even if a large part of the young publics consists of students doing work for their courses. [35]

Yet thanks to the large spaces and in-between areas stairways, hallways or landings - the prohibitions quickly become more supple and only a year later, despite the presence of the security guards, the spaces are redesigned so that the barriers are more porous between accepted practices (listening to music in groups; group study across two tables; occupying a group room without reservation; taking advantage of a closed space dedicated to singing) and tolerated practices (two people reading a comic while sitting on the arms of an armchair; talking on the phone in front of a window; speaking freely on a staircase landing; sleeping; lying down on a sofa). At first the change in practices comes from the users; then, as a result of the attention the staff pay to how the public actually uses the various places and objects, whether these uses are compliant, somewhatcompliant, or non-compliant [47]. Management and the team of librarians gradually modify the furnishings, the decoration, and the display of materials based on the user behavior they have observed. As a result, the spaces (with regard to both the furniture and the bodily hexis of the other individuals present) come to blur the boundaries between what can be done, what is tolerated, what can be hidden, what must be hidden, etc.

6 This strategy is found quite often in the structuring of groups of high school and university students in study activities at both city and university libraries, and it confirms, among other things, the lucidity of both the boys and girls in identifying the mixed group as being more capable of reassuring library workers. [45]

7 The overrepresentation of men in jobs linked to information technology provides a glimpse of one dimension of the job of the library professional that is less characterized by the written word and knowledge, and more open to interactions with the publics. The same majority male presence characterizes music libraries, video libraries, and multimedia libraries (computer rooms with digital documentation and online press training workshops). [41, 46] 
Movement and noise remain two phenomena that both girls and boys engage in constantly, though they present differentiated forms of expression: for example, upon receiving an unexpected phone call, a girl, who is sitting in armchair reading a comic, gets up and rushes to a sheltered nook between the elevator and the window; a boy, seated at a study table with two of his cohorts, begins a phone conversation and, very slowly, urged by the other two who glance warily at the reception desk, moves toward the stairs, making no effort to conceal himself. The slowness of moving and the exhibition of the phone conversation are absolutely prohibited by the norm of silence governing this place. While the girl views the call as violating the rule and the framework (explaining her rush to leave), the boy sees the phone conversation as a part of the framework, his studying is social, interactive, continuous (both with his two companions and in his permanent potential connection to the outside). For the boy, the multimedia library does not impose an institutional framework implying a withdrawal from his personal practices, especially activities for which he is equipped and connected. [34] Reading-book and conversation-phone are mutually hybridized, such that neither the modes nor the representations associated with these two activities (reading, conversation) and these two media (book, telephone) are neutral any longer. Reading and conversation are perceived and reproduced according to two norms that perfectly espouse the general female and male attitude in this place. We note that the forms of hybridization of activities are more explored on the male side, both because the uses of equipment by boys are more likely to test the bounds of permissiveness and because, as with school assignments [13] boys are less likely to yield to instructions than bend those instructions to their own will. This resistance to implicit expectations makes boys the richest and surest lever through which changes slips into the modes of reception and appropriation of public facilities. Due to their borderline position in terms of practices and behavior, they are well placed to find cracks revealing the contradictions, rigidities, and paradoxes in institutional systems. Though they are rare in public spaces, we do find adolescent boys who read comics and mangas for pleasure, sitting in armchairs silently and alone. Regardless of the fact that the figure of the lone male readers appears $75 \%$ less frequently than that of its young female counterpart, ${ }^{8}$ what should be underlined here is that this figure of the solitary reader, whether male or female, is completely absent in smaller local libraries.

Large spaces, indeed, allow young people to get lost in the masses, to copy types of behavior from a pool of examples that are heterogeneous, not hardened around strongly-marked identities (age, rank among siblings, sex). The same individuals, who will never touch a book in a local library, can afford a moment's read without losing face in front of their friends because they can hide, isolate themselves, cheat what they are normally allowed to do without arousing the teasing of their peers [30], even the stigmatization and

8 Doing quantitative work on qualitative data is intriguing because the recurrences and frequencies of the profiles and situations are immediately grasped in terms of sex and age. [15] exclusion to which boys who admit to loving reading expose themselves. [9] The more voluminous spaces available in multimedia libraries and the distance from one's neighborhood of residence and acquaintances thus open up original possibilities. For example, the forms for expressing virility change according to place and situation: while typically exaggerated when one wants to stand out as an individual, the expression of virility can emerge in far more nuanced forms, getting lost in the crowd and setting aside the virile dimension or the game of self-presentation. Put another way, while sexuation strongly influences social contacts characterized by proximity and familiarity, its impact is attenuated in social ties that unfold in anonymous places where the stakes are more numerous and intermingled. Interactions in the multimedia library thus seem more relaxed, being less encumbered by stakes linked to place (among siblings or families, with adults, with peers). Far from one's neighborhood, individuals are not reduced to a single dimension, the one that is most superficial; boys can thus explore the entire range of social contacts, being, at the same time, students, friends, boys and young people. Visits to or periods spent at the multimedia library, however, generally occur in groups.

The changes that the large multimedia library in downtown Toulouse has managed to enact since its opening, with substantial changes occurring every six months, are powerful signs of library professionals' sensibility to users, and of the centrality of the latter in the apparatus's evolution. We are in the presence of a team of librarians that asks questions and inscribes its practices in a reflexivity and an awareness of the power of specific injunctions ("do not do" or "do," as in the case of the memorable words beneath a wooden sculpture: "Please Touch"), objects (such as the three-dimensional books once displayed behind glass, and today hung from strings between the shelves), and layouts (armchairs with window views, but that the librarians cannot see).

\subsection{The Noisy Clusters of Youth: Better Outside Than In?}

The last word returns to the importance of accepting and comfortably installing groups of young people (students or otherwise) in the library. During inquiries, one must always take care to observe those who remain outside. A glance at the exterior of these institutions shows that many young people meet outside of them (in all seasons, especially in working-class neighborhoods). These extra-library spaces are objective extensions of the interior and are organized around groups of adolescents and young adults. The adjacent exterior spaces are intermediary zones between culture and youth sociability, between the free time, time for oneself, and time with others that adolescents have no desire to separate. Sometimes librarians are not very welcoming to exploring, boisterous groups of adolescents, but we often observe that such nonchalant attitudes gradually self-regulate. The group visit can evolve toward a progressive disciplining of bodies and gestural techniques, a sort of conforming to the norms in force to avoid being left out. This highlights the integrating and socializing function of the library, regardless of the real 
difficulties these groups can cause.

Groups deserve particular attention because of the dual role they play in overcoming the within-oneself and in the overflowing of self. The mediation of the group and the solidarity that emerges as a force for working-class and suburban boys are two powerful levers of action. Like the working-class youths who venture in groups into the Toulouse use to the utmost the protection and the reaffirmation of self that groups can provide. They keep themselves together physically (staying close together, making physical contact, walking together), restrain one another, and conform to the library's norms.

Sociologists have noted the emergence of the group, a cognitive and relational space, proposed as a counterpoint to other more conventional figures of readers. Mobilization as a group is thus stimulating for each and every person contained within it. $[2,12]$ And students' search for places to meet one another is not that different from strategies in organizations that aim to maintain physical and verbal contact against the alienating effect of electronic communication [8]. The group at the library fulfils a social function, just as it contributes to weakening among young people the barriers of sex symbolized by a clear division between reflection and abstraction, on the one hand, and a practical relationship with the world on the other. [52] It can also provide a scene for experimenting with new emotions because it allows boys and girls to measure their respective efforts in intellectual work, to observe these efforts palpably in the bodies of others, and to generate emotions akin to the sentiment of solidarity and kindness. [42]

One of the forces that seems to be at work in the acculturation of young adults in the library is group-driven mimicry. Already known for its qualities of sharing and exchange, the group is, more than ever, a key stimulus. Technological innovation has amplified the role of social activity in cultural practices, and not just among young people. You do things with the people that are important to you, by sharing, by conversing, as a mobile and collaborative activity, neither solitary nor sedentary. The place of the group, in its numerous modalities, is one of the leads to follow-up: the group not just as context for work but as a relational framework particularly attractive for young people, in order to rethink the layout of the library's spaces.

The barrier preventing non-users from returning to the library is the impossibility of a relaxing, light-hearted experience, of engaging in both activities that are suggested and others that are not without being disqualified, downgraded or reprimanded for these unorthodox practices. For library professionals, it is a matter of accepting these disorderly, unexpected activities by fully inserting them in the new dematerialized, collaborative, laidback context suggested by young users. Rather than suffering the successive revolutions of the computer, electronic and digital age, libraries could embrace the uses of these connected spaces where young people, both boys and girls, spend much of their time: advertising the library and what it offers, promoting outside the building and on the internet news, photos, events, launches and conferences, and establishing themed partnerships with other public and commercial structures (bookstores, movie theaters, museums, festivals, etc.) would be a normal way of existing in the local public and cultural space and, most importantly, of getting in sync with what the population is doing.

\section{Conclusion}

Tackling the problem posed by the library space when it is designed around the book, for the book, and by book-minded people, Céline Leclaire, in charge of documentary policy and the adult hub of the Roubaix Multimedia Library, suggests that the library be organized like a lived space, starting from what the public actually does with the consoles, the keyboards, the screens, and video games. [23] She thus advocates dance demonstrations to introduce librarians to the body language that, for the moment, they seem incapable of reading in their publics of young people. This would be "a chance for the librarians themselves - and, indirectly, for the users - to adopt a new sort of mobility, a different physical behavior." Movement, a term antagonistic to the classic seated, immobile posture, is another possible way forward. Movement of users, but also movements of the personnel who manage and animate the library. In all studies conducted on users, the absence of interactions with librarians has seemed to arise from the fact that the latter remained behind reference desks, rather than being out in the shared space [37]; that they essentially interacted by way of a screen, rather than handling a medium directly.

To conclude, we can sum up the results of the various sociological studies carried out at and on the library in three essential points $[36,51]$. First, the relationship with library's publics is, first and foremost, a service-based relationship that has everything to gain from being a direct, physical and personal interaction with users. Second, libraries have the potential to become one-stop shops, offering commercial and cultural services and goods that attract all types of people, from a wide range of social and cultural horizons. And third, library spaces, objects and furniture are more than capable of providing facilities for those young people (particularly in the 12-17 age bracket) most likely not to use the library as a place for reading.

\section{References}

[1] ABF-GIF-BPI (Association des Bibliothécaires de FranceGroupe Ile-de-France-Bibliothèque Publique d'Information) (1998, second ed. 2006) Bibliothécaires en Ile-de-France: autoportrait d'un groupe professionnel. Les cahiers du GIF. CNFPT/Direction des Affaires Culturelles d'Ile-de-France, Paris, TdD33_Bibliothecaires en prospective_2006.pdf.

[2] Barrère, A. (1997) Les lycéens au travail. Tâches objectives, épreuves subjectives, Presses Universitaires de France, Paris.

[3] Baudelot, C., Cartier, M., Détrez, C. (1999) Et pourtant ils lisent..., Le Seuil, Paris. 
[4] Bertrand A-M. (1999) Les bibliothèques, La Découverte, Paris.

[5] Bertrand A.-M. et al. (2001) Les bibliothèques municipales et leurs publics: pratiques ordinaires de la culture, BPI/Centre Georges Pompidou, Paris.

[6] Bourdieu, P. (1979) La distinction. Critique sociale du jugement, Minuit, Paris.

[7] Coulangeon, P. (2005) Sociologie des pratiques culturelles, La Découverte, Paris.

[8] De Rosa, C. (2006) College students' perceptions of libraries and information resources: a report to the OCLC membership, OCLC Online Computer Library Center, Dublin, Ohio. Print. https://www.oclc.org/content/dam/oclc/reports/pdfs/studentper ceptions.pdf.

[9] De Singly, F. (1991) L'engagement dans la lecture chez les collégiens: inégal et fragile. In (eds) Privat, J.-M. \& Reuter, Y.: Lectures et médiations culturelles, Presses Universitaires de Lyon, Villeurbanne, 99-113.

[10] Détrez, C. (2003) Rapports à la lecture, adolescence et «genre». In (eds) Donnat, O. \& Tolila, P.: Le (s) public (s) de la culture, 2 volumes (the 2nd on CD-ROM), Presses de Science Po, Paris, 119-127.

[11] Donnat, O. (2005) Féminisation des pratiques culturelles. Développement culturel, Bulletin du Département des Etudes, de la prospective et des Satistiques du Ministère de la Culture et de la Communication, 147: 2005, https://www.cairn.info/femmes-genre-et-societes-9782707144126-page-423.htm\#.

[12] Dubet, F. \& Martuccelli, D. (1996) A l'école. Sociologie de l'expérience scolaire, Seuil, Paris.

[13] Duru-bellat, M. (1995) Filles et garçons à l'école, approches sociologiques et psycho-sociales. Revue française de Pédagogie, 2nd part: La construction scolaire des différences entre les sexes, 110: 75-109.

[14] Forlani, S. (2010) Femmes, pouvoir et bibliothèques: l'accès aux hautes fonctions dans les bibliothèques françaises, mémoire d'étude de conservateur de bibliothèque (dir. Bertrand, A.-M.), Ecole Nationale Supérieure des Sciences de l'Information et des Bibliothèques (ENSSIB), Villeurbanne. Print, https://www.enssib.fr/bibliothequenumerique/documents/48195-femmes-pouvoir-etbibliotheques.pdf.

[15] Given, L. M. \& Leckie, G. J. (2003) Sweeping the Library: Mapping the Social Activity Space of the Public Library. Library and Information Science Research, 25: 365-385, https://www.semanticscholar.org/paper/Sweeping-thelibrary\%3A-Mapping-the-social-activity-1-GivenLeckie/5b5a25dd9716507e7456e962412a9556a5a2d30b.

[16] Goblot, E. (1925, last ed. 2010) La barrière et le niveau (étude sociologique sur la bourgeoisie française), Presses Universitaires de France, Paris.

[17] Goulet V. (2017) Les bibliothécaires sont-ils vecteurs d'inégalités?. Médiapart.fr, June 23, www.ugr.es/ alozano/Translations/SweepingtheLibrary.pdf.

[18] Hedjerassi, N. (2003), La fréquentation par la bande. In (eds) Martine Burgos et al.: Des jeunes et des bibliothèques. Trois études sur la fréquentation juvénile, BPI/Centre Pompidou, Paris, 21-78.
[19] Horellou-Lafarge, C. \& Segré, M. (2007) Sociologie de la lecture, La Découverte, Paris.

[20] Jiao, Q. J. \& Onwuegbuzie, A. J. (1997) Antecedents on library anxiety. Library Quarterly, 67/4: 372-389, https://www.journals.uchicago.edu/doi/abs/10.1086/629972.

[21] Lahire, B. (2001) Héritages sexués: incorporation des habitudes et des croyances. In (ed) Blöss, T.: La dialectique hommesfemmes, Presses Universitaires de France, Paris, 9-21.

[22] Lahire, B. (2004) La culture des individus. Dissonances culturelles et distinction de soi, La Découverte, Paris.

[23] Leclaire, C. (2010) S'asseoir, braconner, se courber: le vocabulaire des corps à la médiathèque. Bulletin des bibliothèques de France (BBF), 55/ 6: 59-64, https://bbf.enssib.fr/consulter/bbf-2010-06-0059-001 ISSN 1292-8399.

[24] McCurdy, D. W., Spradley J. P. \& Shandy D. J. (2005) The Cultural Experience: Ethnography in Complex Society, Long Grove (IL): Waveland Press (second edition).

[25] Maresca, B., Evans C. \& Gaudet F. (2007) Les bibliothèques municipales en France après le tournant Internet. Attractivité, fréquentation et devenir. Enquête DLL-CREDOC (Direction du Livre et de la Lecture et Centre de Recherche pour l'Etude et l'Observation des Conditions de Vie), BPI/Centre Pompidou, Paris.

[26] Ministère de la Culture et de la Communication (2016) Publics et usages des bibliothèques municipales en 2016, Direction Générale des Médias et des Industries culturelles, TMO Grandes Enquêtes, Paris, https://www.culture.gouv.fr/Sites-thematiques/Livre-etlecture/Actualites/Enquete-sur-les-Publics-et-les-usages-desbibliotheques-municipales-en-2016.

[27] Observatoire CNFPT (2001) Enquête démographique sur les personnels des bibliothèques, Ministère de la Culture \& Ministère de l'Education Nationale, Paris, www.culture.gouv.fr/culture/dll/enquete/demographie.pdf.

[28] Octobre, S. (2004) Les loisirs culturels des 6-14 ans, La Documentation Française, Paris.

[29] Octobre, S., Détrez, C., Mercklé, P. (2011) L'enfance des loisirs. Trajectoires communes et parcours individuels de la fin de l'enfance à la grande adolescence. La Documentation française, Paris.

[30] Pasquier, D. (2003) Des audiences aux publics: le rôle de la sociabilité dans les pratiques culturelles. In (eds) Donnat, O. \& Tolila, P.: Le (s) public (s) de la culture, 2 volumes (the 2 nd on CD-ROM), Presses de Science Po, Paris: 109-117.

[31] Passeron, J.-C. (1991) Figures et contestations de la culture. Légitimité et relativisme culturel and Le polymorphisme culturel de la lecture. In (ed) Passeron, J.-C.: Le raisonnement sociologique. L'espace non-poppérien du raisonnement naturel, Nathan, Paris: 291-314 and 335-345.

[32] Paugam S. \& Giorgetti C. (2013) Des pauvres à la bibliothèque. Enquête au Centre Pompidou, Presses Universitaires de France, Paris.

[33] Payne, L. A. (1998) Public Library Support for Groups and Users. In (ed) Whitesides, W. L.: Reinvention of the Public Library for the 21st Century, CO: Libraries Unlimited, Englewood, 83-94. 
[34] Pedler E. \& Zerbib O. (2001) Les nouvelles technologies à l'épreuve des bibliothèques. BPI/Centre Georges Pompidou, Paris.

[35] Petite S. \& Le Douarin L. (2008) La diversité des usages et des étudiants au sein de la Médiathèque Jean Lévy à Lille. Bibliothèque (s), 40: 66-68, http://www.enssib.fr/bibliothequenumerique/document-59513\#page $=68$.

[36] Poissenot, J.-C. (1997) Les adolescents et la bibliothèque. Fidélité et désertion. BPI/Centre Georges Pompidou, Paris.

[37] Repaire V. \& Touitou C. (2010) Les 11-18 ans et les bibliothèques municipales. BPI/Centre Georges Pompidou, Paris.

[38] Robine N. (1984) Les jeunes travailleurs et la lecture. La Documentation Française, Paris.

[39] Robine N. (1991). Relais et barrières: la perception de l'aménagement de l'espace et des classifications par les usagers dans les lieux de prêt ou de vente du livre, In (eds) Privat, J.-M. \& Reuter, Y.: Lectures et médiations culturelles. Presses Universitaires de Lyon, Villeurbanne, 115-125.

[40] Roselli, M. (2003) La bibliothèque dans les quartiers défavorisés. Un espace de requalification individuelle. Bulletin des bibliothèques de France (BBF), 6: 74-80, https://bbf.enssib.fr/consulter/bbf-2003-06-0074-001 ISSN 1292-8399.

[41] Roselli, M. (2006) Usagers et usages devant une offre de lecture publique libre: parcours d'acculturation et formes d'appropriation lettrées. Sociétés contemporaines, 4/64: 135151, https://doi.org/10.3917/soco.064.0135

[42] Roselli, M. \& Perrenoud, M. (2010) Du lecteur à l'usager. Enquête ethnographique en bibliothèque universitaire, Presses Universitaires du Mirail, Toulouse.

[43] Roselli, M. (2010) Chemins de rencontre et de mise en commun de savoirs en milieu étudiant. Etude de quatre figures de passeurs. Pensée plurielle, 24/2: 63-78, https://doi.org/10.3917/pp.024.0063.

[44] Roselli, M. (2011) Les enquêtes qualitatives en bibliothèque: quelles techniques pour quels résultats? In (ed.) Evans, C. Mener l'enquête. Guide pratique des études des publics en bibliothèques. Presses de l'ENSSIB, Villeurbanne, 80-92.
[45] Roselli, M. (2011) La bibliothèque, un monde de femmes. Déterminations et conséquences sur la segmentation des publics jeunes dans les bibliothèques. Réseaux, 29/168-169: 133-164, https://doi.org/10.3917/res.168.0133.

[46] Roselli, M. (2014) Cultures juvéniles et bibliothèques publiques: lier récréation et espace culturel. Agora, 66/1: 61-75, https://doi.org/10.3917/agora.066.0061.

[47] Roselli, M. \& Coladant D. (2014) Le livre, l'ordinateur et le fauteuil. Etude des pauvres à la médiathèque José Cabanis (Toulouse), final report to the Chief of Public Library Service of Toulouse.

[48] Roselli, M. (2016) La bibliothèque dans les quartiers populaires. Mondes sociaux, http://sms.hypotheses.org/8718.

[49] Roselli, M. (2016) La construction sociale de la figure de lectrice et de sa contre-figure masculine. Revue de Recherches en Littératie Médiatique Multimodale, 4. Published following the 2016 ANR Translit/International Conference Pratiques et parcours trans-littéraciques, ESPE of the Académie de Rouen, https://doi.org/10.7202/1046990ar.

[50] Roselli, M. (2019) Se retirer pour lire. La place de la solitude élective et les négociations avec la trame sociale. Sociologie et Sociétés, L/1: 67-90.

[51] Roselli M. (2019) La relazione di servizio pubblico in biblioteca: la dimensione sociale della mediazione, AIB Studi. Rivista delle biblioteche e dell'edizione italiana, 59/1-2: 9-29.

[52] Saijad, U. J., Mumtaz A. A. \& Nosheen F. W. (2018) The relationship between emotional intelligence, library anxiety, and academic achievement among the university students. Journal of Librarianship and Information Science, 52/11: 237 248, https://doi.org/10.1177/0961000618790629.

[53] Siblot, Y., Cartier, M., Coutant, I. \& Renehy, N. (2015) Sociologie des classes populaires, Armand Colin, Paris.

[54] Spradley, J. P. (1980) Participant Observation, Holt, Rinehart and Winston, New York.

[55] Zotian, E. (2006) Modes d'usage et d'appropriation. L'exemple des enfants de Belsunce à la Bibliothèque d'Alcazar. Bulletin des bibliothèques de France (BBF), 6: 6874, https://bbf.enssib.fr/consulter/bbf-2006-06-0068-013 ISSN 1292-8399. 